\title{
Intervensi Keperawatan Anak Pada Anak Usia Pra Sekolah Di Kecamatan Weleri Dalam Upaya Pencapaian Tumbuh Kembang
}

\author{
Andriyani Mustika Nurwijayanti ${ }^{1}$, Muhammad Khabib Burhanuddin Iqomh ${ }^{2}$ \\ ${ }^{1,2}$ Program Studi Ilmu keperawatan Sekolah Tinggi Ilmu Kesehatan Kendal. \\ Jalan laut no:31 kendal. Email :andri.manis@yahoo.co.id \\ khabib.ners@yahoo.com
}

\begin{abstract}
Abstrak
Usia pra sekolah merupatan tahapan pertumbuhan dan perkembangan pada anak yang sangat penting. Stimulasi memiliki peran penting dalam keberhasilan pencapaian tumbuh kembang. Stimulasi motorik halus adalah salah satu stimulasi yang dapat diberikan kepada anak usia pra sekolah untuk mencapai perkembangan psikososial. Desain penelitian menggunakan Quasy Experimental dengan pre post test without control group.jumlah sampel 211 responden dengan menggunakan teknik random sampling. Penggumpulan data penelitian menggunakan kuesioner perkembangan psikososial. Usia responden berkisar 4-6 tahun, terdapat 117 responden $(55,5 \%)$ lakilaki dan 94 responden (44,5\%). Perkembangan psikososial pre intervensi yang sesuai usia sebanyak 6 responden $(2,8 \%)$ dan yang tidak sesuai usia sebanyak 205 (97,2\%). Perkembangan psikososial post intervensi yang sesuai usia sebanyak 142 responden $(67,3 \%)$ dan yang tidak sesuai sebanyak $69(32,7 \%)$ Hasil uji analisa statistik dengan menggunakan uji Wilcoxon, mendapat $\mathrm{p}$ value $0,000(\mathrm{p}<0,05)$ terdapat pengaruh stimulus motorik halus terhadap perkembangan anak usia pra sekolah di TK ABA. Penelitian ini menunjukkan terdapat peningkatan perkembangan psikososial anak usia sekolah setelah diberikan stimulasi motorik halus.
\end{abstract}

Kata kunci : : perkembangan psikososial, stimulus motorik halus, usia pra sekolah

\begin{abstract}
Pre-school age is a very important stage of growth and development in children. Stimulus has an important role in the success of achieving growth and development. coloring, cutting, drawing activities are one of the stimuli that can be given to pre-school age children to achieve psychosocial development. Methods: The study design used Quasy Experimental with pre post test without control group. The number of samples was 211 respondents using random sampling technique. Collecting research data using psychosocial development questionnaires. Results: Age of respondents ranged from 4-6 years, there were 117 respondents (55.5\%) men and 94 respondents (44.5\%). Psychosocial development of appropriate pre-intervention age was 6 respondents $(2.8 \%)$ and those who were not age were 205 (97.2\%). Appropriate age post psychosocial development was 142 respondents (67.3\%) and 69 were incompatible (32.7\%). Discussion: Statistical analysis using the Wilcoxon test, obtained $p$ value 0,000 ( $p<0.05)$ there is an effect of fine motor stimulus on the development of pre-school age children in ABA kindergarten. The results showed that there was an increase in psychosocial development of school-age children after being given fine motor stimulus.
\end{abstract}

Keywords : : motor stimulation, pre-school, psychosocial development 


\section{Pendahuluan}

Anak usia pra sekolah(3-6 tahun) memiliki potensi yang besar untuk segera berkembang, potensi tersebut akan berkembang apabila diberilan layanan berupa kesempatan melakukan kegiatan motorik yang dilatih atau digunakan sesuai dengan perkembangan anak tersebut. Besar kecilnya naluri bergerak bagi anak tidak selalu sama. ${ }^{1}$ Anak usia pra sekolahsebaiknya diberikan stimulus supaya perkembangan anak tidak terganggu.

Masa usia pra sekolahmerupakan masa emas, dimana poerkembangan seorang anak akan banyak mengalami perubahan yang sangat berarti. Agar pertumbuhan anak usia pra sekolahdapat optimal maka diberikan stimulus, untuk memberikan rangsangan terhadap seluruh aspek perkembangan anak. ${ }^{2}$ Fase perkembangan psikososial pada anak usia pra sekolahadalah inisiatif dan rasa bersalah. Perkembangan ini diperoleh dengan cara mengkaji lingkungan melalui kemampuan bereksplorasi terhadap lingkungannya. Anak belajar mengendalikan diri dan memanipulasi lingkungan. Anak mempunyai inisiatif berkembang dengan teman sekelilingnya. Kemampuan anak berbahasa meningkat, anak mulai berkembang untuk melakukan tugas dan bisa menghasilkan suatu prestasi. $^{2}$

Perkembangan anak usia pra sekolahdapat mengalami penyimpangan jika tidak diberikan stimulasi, salah satunya stimulus yang diberikan yaitu motorik halus. Perkembangan psikososial anak usia pra sekolahyaitu anak sudah bisa membantu pekerjaan yang sederhana, anak bisa bermain sesuai jenis kelamin, makan bersama keluarga dan bermain peran

Tahap perkembangan motorik halus anak usia 3-6 tahun meliputi beberapa aspek motorik halus yang terdiri dari; membangun menara setinggi 11 kotak, menggambar sesuatu yang berati bagi anak tersebut dan dapat dikenali oleh orang lain, mempergunakan gerakan-gerakan jemari selama permainan jari, menjiplak gambar kotak, menulis beberapa huruf. Anak usia 5 tahun mempunyai kemampuan pada aspek motorik halus yang terdiri dari; menulis nama depan, membangun menara setinggi 12 kotak, mewarnai garisgaris, memegang pencil dengan benar antara ibu jari dan dua jari, menggambar orang beserta rambut hidung, menjiplak persegi panjang dan segitiga, memotong bentukbentuk sederhana. ${ }^{3}$

Tahap perkembangan motorik halus anak akan mampu dicapai secara optimal asal mendapatkan stimulasi tepat. Setiap fase, anak membutuhkan rangsangan untuk mengembangankan kemampuan mental dan motorik halusnya. Semakin banyak yang dilihat dan didengar anak, semakin banyak yang ingin diketahuinya sehingga kurang mendapatkan rangasangan anak akan bosan. Orang tua tidak boleh menberikan tekanan, persaingan, penghargaan, hukuman, dan atau rasa takut dapat mengganggu usaha yang dilakukan anak. ${ }^{4}$

Perkembangan motorik yang terlambat berarti perkembangan motorik yang berada dibawah normal umur anak sehingga timbul dari kerusakan otak pada waktu lahir atau kondisi sebelum lahir, yang tidak menguntungkan atau lingkungan yang tidak menyenangkan setelah lahir namun keterlambatan lebih sering di sebabkan oleh kurangnya kesempatan untuk mempelajari keterampilan motorik, perlindungan orangtua yang berlebihan, atau kurangnya motivasi anak untuk mempelajarinya. ${ }^{5}$

Perkembangan anak membutuhkan stimulasi. Anak yang mendapat stimulasi yang terarah adan teratur lebih cepat berkembang dibandingkan dengan anak yang kurang/tidak mendapat stimulasi. ${ }^{6}$ Perkembangan emosi dan sosial mencakup proses ketika anak belajar nilai-nilai dan tingkah laku yang diterima oleh lingkungan. Dalam aspek ini anak diperkenalkan tentang pengertian terhadap diri sendiri, tanggung jawab terhadap dan orang lain, serta perilaku proposial. Ini termasuk memperkenalkan kemampuan untuk mengikuti aturan dan rutinitas, kemampuan empati, berbagi, dan lain-lain .

Berdasarkan data diatas maka peneliti tertarik untuk meneliti dengan judul pengaruh stimulasi motorik halus terhadap tahap perkembangan psikososial anak pra sekolah(36 tahun) di TK ABA Kecamatan Weleri Kabupaten Kendal. Penelitian ini bertujuan untuk mengetahui pengaruh stimulus motorik halus terhadap perekembangan psikososial anak usia sekolah.

\section{Metode}

Jenis penelitian yang dilakukan pada penelitian ini adalah penelitian quasi 
eksperimen dengan pre post test without control group.

Sampel adalah sebagian dari jumlah dan karakteristik yang dimiliki oleh populasi, atau sampel adalah sebagian dari populasi yang dapat digunakan sebagai subjek peneliti melalui sampling ${ }^{7}$. Populasi dalam penelitian ini adalah semua anak usia pra sekolah yang sekolah di 6 TK ABA di Kecamatan Weleri. Sampel penelitian sebanyak 211 anak.

Alat penelitian adalah fasilitas yang digunakan oleh peneliti dalam mengumpulkan data agar bekerja lebih mudah dan mendapatkan hasil yang terbaik (cermat, lengkap dan sistematis) sehingga pengolahannya lebih mudah. ${ }^{7}$ Alat penelitian dalam penelitian ini adalah dengan kuesioner yang dibuat berdasarkan teori perkembangan psikososial. Kuesioner merupakan alat ukur berupa angket atau kuesioner dengan beberapa pertanyaan atau pernyataan. ${ }^{7}$ Uji validitas instrumen menggunakan uji korelasi Pearson Product Moment dengan membandingkan nilai $r$ tabel dengan $r$ hitung, dimana instrumen dianggap valid jika nilai $r$ hitung lebih besar dari nilai $r$ table ${ }^{8}$. Berdasarkan hasil dari uji validitas semua item pertanyaan dinyatakan valid dengan nilai $r$ lebih besar dari 0,444 dengan taraf kesalahan 5\% dengan nilai 0,5130,778 .

Hasil uji reliabilitas didapatkan hasil 0,890 , hasil tersebut lebih besar dari 0,6 dan mendekati angka satu sehingga dinyatakan reliable. Reliabilitas menunjukkan sejauh mana hasil pengukuran relatif konsisten jika dilakukan pengukuran berulang-ulang dari waktu ke waktu. Pada penilitian ini dilakukan uji internal consistency yaitu mengujikan instrumen sekali saja. Jika hasil perhitungan mendekati nilai 1 maka dianggap reliabel. Untuk menentukan reliabilitas terhadap butirbutir pernyataan variabel dilakukan pengujian dengan Cronbach's Alpha.

Pelaksanaan penelitian melibatkan asisten peneliti yang diambil dari mahasiswa tingkat profesi tingkat akhir dan sudah menyandang gelar Sarjana Keperawatan. Penelitian dilakukan di TK ABA Kecamatan Weleri, Kabupaten Kendal.

Analisis pada variabel-variabel di dalam penelitian ini dilakukan secara univariat, dan bivariate. Analisis univariat digunakan untuk mendeskripsikan hasil penelitian dari masing- masing variabel yang diteliti. Analisis bivariat digunakan untuk mengetahui pengaruh antara variabel terikat dan variabel bebas.

\section{Etika Penelitian}

Ketika seseorang dipilih untuk ikut serta dalam penelitian, peneliti harus memastikan bahwa hak-hak dari responden terlindungi. Prinsip-prinsip etik yang perlu diperhatikan dalam penelitian diantaranya adalah beneficence, human dignity dan justice. ${ }^{9}$

Beneficence yaitu prinsip manfaat ini meliputi bebas dari penderitaan, bebas dari eksploitasi serta pertimbangan risiko dan keuntungan yang akan berakibat pada responden karena kegiatan selama penelitian. human dignity Hak ini meliputi hak untuk ikut dalam penelitian atau menolak menjadi responden dalam penelitian. Justice hak untuk memdapatkan perlakuan yang adil dan hak dijaga kerahasiaannya.

\section{Hasil}

Tabel 1 Distribusi Responden berdasar Usia

\begin{tabular}{ccccc}
\multicolumn{5}{c}{$(\mathrm{n}=211)$} \\
Variabel & Mean & SD & $\begin{array}{c}\text { Minimum- } \\
\text { Maximum }\end{array}$ & $\begin{array}{c}95 \% \\
\mathrm{CI}\end{array}$ \\
\hline \multirow{2}{*}{ Usia } & 4,63 & 0,71 & $4-6$ & $4,5-$ \\
& & & & 4,73 \\
\hline
\end{tabular}

Tabel $1 \mathrm{di}$ atas dapat dilihat bahwa rata-rata usia responden adalah 4,6 tahun (95\% CI: 4,54,73).

Tabel 2 Deskriptif Karakteristik Responden Berdasarkan Jenis Kelamin, Perkembangan Psikososial pre dan post intervensi

$(n=211)$

\begin{tabular}{lcc}
\hline \multicolumn{1}{c}{ Variabel } & Frekuensi & Persentase (\%) \\
\hline Jenis kelamin & & 55,5 \\
Laki-laki & 117 & 44,5 \\
Perempuan & 94 & 100 \\
\hline Total & 211 & \\
\hline
\end{tabular}

\begin{tabular}{lcc}
$\begin{array}{l}\text { Perkembangan } \\
\text { psikososial pre } \\
\text { intervensi }\end{array}$ & & \\
\hline Sesuai & 6 & 2,8 \\
Tidak sesuai & 205 & 97,2
\end{tabular}




\begin{tabular}{lcc}
\hline Variabel & Frekuensi & Persentase (\%) \\
\hline Total & 211 & 100 \\
\hline
\end{tabular}

\begin{tabular}{lcc}
$\begin{array}{l}\text { Perkembangan } \\
\text { sosial post } \\
\text { intervensi }\end{array}$ & & \\
\hline Sesuai & 142 & 67,3 \\
Tidak sesuai & 69 & 32,7 \\
\hline
\end{tabular}

Mayoritas responden berjenis kelmain laki-laki yaitu sebanyak 117 responden (44,5 $\%)$. Perkembangan psikososial sebelum dilakukan intervensi mayoritas tidak sesuai usia yaitu sebanyak 205 (97,2\%). Perkembangan psikososial setelah dilakukan intervensi mayoritas sesuai usia yaitu sebanyak 142 anak $(67,3 \quad \%)$.

Tabel 3. Analisis Uji Wilcoxon Perkembangan Psikososial Anak Usia Pra Sekolah Sebelum Dan Sesudah Dilakukan Stmulasi Motorik Halus Di TK ABA

$(n=211)$

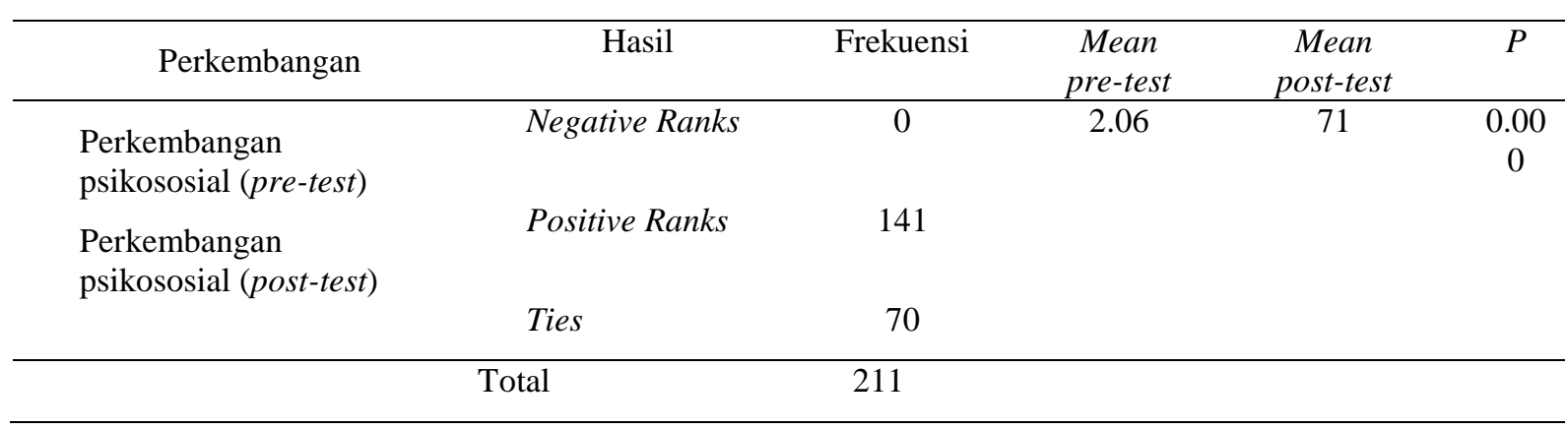

Langkah selanjutnya untuk mengetahui pengaruh pengaruh stimulasi motorik halus terhadap perkembangan psikososial pada pada anak usia pra sekolah di TK ABA dengan 211 responden, dilakukan uji wilcoxon karena data yang diperoleh berdasarkan hasil uji normalitas menggunakan uji shapiro wilk menunjukkan data terdistribusi tidak normal. Terdapat perbedaan perkembangan psikososial setelah dilakukan pemberian stimulus motorik halus, yaitu terdapat 141 responden dengan hasil perkembangan psikososial yang sesuai usia lebih tinggi dari pada sebelum intervensi. Hasil uji analisis statistik dengan menggunakan uji Wilcoxon diperoleh nilai $p$ value adalah 0,000 $(p<0,05)$ yang berarti terdapat perbedaan yang bermakna antara sebelum dan sesudah pemberian intervensi stimulus motorik halus. $\%)$. Mean dari total responden 71.

\section{Pembahasan}

Anak pra sekolahmerupakan anak yang berusia antara 3-6 tahun yang belum menempuh pendidikan di sekolah dasar. Hasil penelitian menunjukkan bahwa usia anak yang bersekolah di TK ABA rata-rata berusia 4.6 tahun dengan usia tertua adalah 6 tahun. Anak usia pra sekolahdisebut juga dengan masa keemasan (Golden period) karena, masa dimana kemampuan otak anak untuk menyerap segala bentuk informasi sangat tinggi, karena sekitar $80 \%$ otak anak berkembang pada periode emas.

Perkembangan adalah suatu perubahan progresif dalam organisasi organisme, dan organisme dilihat sebagai sistem fungsional dan adaptif sepanjang hidup. Perubahan progresif meliputi ortogenetikdan filogenetik. Perubahan ortogenetik berhubungan dengan perkembangan sejak terbentuknya individu yang baru dan seterusnya sampai individu itu dewasa, sedangkan perubahan filogenetik yaitu perkembangan yang berawal dari asal usul manusia sampai saat ini. ${ }^{10}$

Periode pra sekolah, anak mengalami pertumbuhan dan perkembangan yang signifikan baik fisik maupun mental. ${ }^{11}$ Hasil penelitian menunjukkan bahwa usia responden merupakan anak usia pra sekolahdan sedang dalam masa keemasan, sehingga pada masa balita ini perkembangan kemampuan berbahasa, kreativitas, kesadaran sosial dan intelegensi berjalan sangat cepat dan merupakan landasan perkembangan bagi kehidupan anak di tahap berikutnya. Apabila setiap kelainan atau penyimpangan sekecil apapun jika tidak terdeteksi atau tidak ditangani dengan baik, maka akan mengurangi 
kualitas sumber daya manusia di masa yang akan dating. ${ }^{2}$

Anak-anak pra sekolah tidak siap untuk terlibat dalam permainan dengan aturan, sehingga anak yang berada pada tahapan in cenderung bermain sesuai dengan egonya. Anak usia prasekolah adalah anak yang berumur 3-6 tahun, dimana anak sudah siap belajar dan mengenal lingkungan luar yang lebih luas. Pada usia prasekolah, anak Pada masa ini, anak akan di didik kemampuan motorik ataupun psikososial melalui permainan

Hasil penelitian menunjukkan bahwa jenis kelamin anak mayoritas laki-laki sebanyak 117 (55.5\%) sedangkan anak perempuan sebnayak $94 \quad(44,5 \%)$. Soetjiningsih (2014) menyatakan bahwa salah satu faktor yang mempengaruhi tumbuh kembang adalah lingkungan biologis, anak laki-laki sering mengalami gangguan pertumbuhan dan perkembangan dibandingkan anak perempuan.

Hasil penelitian Listyorini dan Zulaicha (2009) yang menyatakan bahwa, pada usia pra sekolah anak perempuan cenderung lebih menyesuaikan diri dibandingkan dengan anak laki-laki. Perempuan mampu mengingat sejumlah gambaran emosi yang jauh lebih baik dibandingkan laki-laki dan secara emosional perempuan jauh lebih efektif dibandingkan dengan laki-laki dalam pemerolehan bahasa secara alamiah. Perkembangan emosional anak perempuan lebih cepat matang dibandingkan anak laki-laki.

\section{Pengaruh Pemberian Stimulus Mewarnai, Menggunting, Menggambar Pola Terhadap Perkembangan Psikososial.}

Anak pra sekolahadalah anak yang berusia 3-6 tahun. Pada masa ini, terjadi pertumbuhan biologis, psikologis, kognitif, dan spiritual yanh begitu signifikan ${ }^{11}$.. Masa pra sekolahmerupakan masa-masa untuk bermain dan mulai memasuki taman kanak-kanak. Waktu bermain merupakan saranan untuk tumbuh dalam lingkungan dan kesiapannya dalam belajar formal ataupun informal.

Gangguan perkembangan yang muncul pada usia pra sekolah menunjukkan bahwa anak mengalami penyimpangan atau ketidaksesuaian perkembangan berdasarkan usia. Kurang mampu bersosialiasi, kurang inisiatif, pendiam, takut salah dalam bertindak menunjukkan ada masalah psikososial.
Perkembangan pada anak meliputi perkembangan bahasa, motorik kasar dan halus, perkembangan personal sosial/psikososial. Perkembangan psikososial adalah perkembangan kepribadian manusia yang berkaitan dnegna emosi, motivasi dan perkembangan kepribadian yang berkaitan dengan hubungan sosial, perkembangan psikososial berlangsung selama masa tahapan usia dan dipengaruhi oleh pengalaman

Perkembangan psikososial anak usia pra sekolah meliputi inisiatif versus kesalahan. Tahap inisisatif merupakan masa untuk memperluas penguasaan dan tanggung jawab dengan melakukan interaksi dengan lingkungan tempat anak menjalankan aktivitas. Pada tahapan ini, anak memliliki rasa ingin tau yang besar, jika anak menadapatkan pola asuh yang salah maka anak kan cendenrung merasa bersalah, berdiam diri dan sifat ini akan cenderung bertahan sampai dewasa.

Permainan yang diberikan pada anak akan merangsang ide berimajinasi dan kreativitas. Permainan dapat membantu perkembangan kognitif dan memberikan kontribusi pada perkembangan kecerdasan. Permainan dapat berupa bermain aktif dengan menggunakan motorik kasar seperti melompat dan berlari. selain motorik kasar, permainan yang melibatkan motorik halus seperti mewarnai, menggambar, dan menggunting sangat bermanfaat bagi anak usia pra sekolah. Permainan motorik halus sangat baik bagi anak, antara lain: 1). Menciptakan gerakan dan kordinasi mata, tangan dan anggota badan yang lain. 2). Melepas ketegangan di dalam diri anak dan membuat perasaan dorongan yang membuat perasaan tenang pada anak. 3). Anak mampu memahami diri sendiri dengan menentukan pilihan yang sedang anak mainkan, anak mampu mengendalikan diri. 4). Anak dapat mengembangkan kepercayaan diri dengan mengembangkan fisik, sosial, keterampilan dan intelektual. 5). Membantu anak mengekspresikan diri. 6). Meningkatkan kreativitas. 7). Membantu anak bersosialisasi. 8). Berlatih memecahkan masalah.

Permainan yang menggunakan imajinasi sebaiknya diberikan setelah anak berusia 3 tahun. Aktivitas menulis, menggambar, mewarnai, menggunting atau membuat prakarya, ternyata memiliki banyak manfaat bagi anak. Aktivitas kreatif tidak hanya dapat melatih keterampilan motorik halus dan daya 
imajinasi anak, tetapi juga memiliki manfaat terapeutik atau penyembuhan untuk beberapa gangguan atau kendala psikologis. Ketika menggambar, mewarnai dan menggunting, , anak akan mengalami proses kreatif, imajinasi, mengeksplor emosi berupa pelepasan energi negatif. Manfaat kegiatan menggambar antara lain: 1). Menyalurkan ekspresi negatif, karena anak sedang berkreasi anak akan melepas tekanan/beban yang dirasakan. 2). Melancarkan komunikasi. 3). Mengatasi gangguan mental dan trauma, anak-anak rentan mengalami masalah gangguan kesehatan mental, misalnya: cemas. Anak yang tidak mengalami msalah mental akan melampiaskan dnegan menangis, marah bahkan menyakiti diri sendiri.

Stimulus yang tepat sesuai dengan kebutuhan tahapan usia akan membantu anak dalam mencapai perkembangan psikososial yang optimal. Hasil penelitian menunjukkan bahwa terdapat pengaruh pemberian stimulus motorik kasar berupa menggambar, menggunting dan mewarnai dengan perkembangan psikososial $(p=0,000)$. Dari 211 responden, terdapat 6 anak $(2,8 \%)$ yang memiliki perkembnagan psikososial sesuia usia. Setelah dilakukan stimulasi motorik halus dengan menggambar, menggunting, menggambar pola terdapat kenaikan jumlah anak yang perkembangan psikososial sesuai dengan usia yaitu menjadi 142 anak (67\%).

Hasil penelitian dilihat dari quesioner pertanyaan yang diajukan berupa lawan kata, mayoritas anak menjawab dengan salah dan cenderung malu untuyk menjawab. Dari 211 responden, anak yang dianggagap mampu menjawab dengan benar sebannyak 59 (28\%) dan pertanyaan tentang kemampuan mengikuti permainan dengan teman sebaya sebanyak 71 anak $(33,6 \%)$. Hal ini menunjukkan bahwa anak takut menjawab karena salah. Sedangkan terkait kemampuan untuk mengikuti permainan dengan teman sebaya, anak cenderung untuk menuruti egonya sehingga sulit mengikuti aturan permainan. Setelah diberikan stimulus permainan, kemampuan kooperatif anak menjadi 178 anak. hal ini sesuai dengan penelitian yang dilakukan oleh. ${ }^{15}$ tentang pengaruh terapi bermain terhadap tingkat kooperatif anak, hasil penelitian mendapatkan hasil bahwa pemberian terapi bermain dapat meningkatkan perilaku kooperatif anak. kemampuan kooperatif anak dalam meningkatkan kooperatif dipengaruhi oleh usia anak. hasil penelitian ini sesuai dengan prinsip tumbuh kembang yaitu perkembangan berjalan bersamaan dnegan pertumbuhan. Setiap pertumbuhan disertai dengan perubahan fungsi, perkembnagan intelegensi akan bertambah seiring pertumbuhan anatomis. Seiring bertambahnya usia, maka daya nalar, emosi, peningkatan mental dan lain-lain.

Pada periode ini tubuh menjadi lebih panjang dan lebih ramping. Keterampilan motor juga menjadi lebih baik. Anak-anak pada periode ini lebih mampu mengontrol diri dan mengurus dirinya sendiri. Mereka juga mengembangkan keterampilan kesiapan sekolah (seperti kemampuan mengikuti instruksi, mengenal huruf), dan menghabiskan banyak waktunya untuk bermain bersama teman. Hal tersebut didukung pula oleh perkembangan berpikir dan bahasa yang luar biasa.

Dalam melakukan stimulasi tumbuh kembang anak, ada beberapa prinsip dasar yang perlu diperhatikan yaitu: dilakukan rasa cinta dan kasih sayang, menunjukan sikap dan perilaku yang baik memberikan sesuai dengan kelompok umur, bentuk stimulais adalah kegiatan mneyenangkan (bermain, bernyanyi, tanpa paksaan, menyenangkan dan tidak ada hukuman), gunakan alat bantu atau permainan yang sederhana, aman dan ada disekitar anak, berikan kesempatan yang sama pada anak lakilaki dan perempuan, berikan pujian atas keberhasilannya. ${ }^{17}$

Hasil penelitian menunjukkan masih ada anak yang perkembangan psikososial belum sesuai usianya. Banyak faktor yang mempengaruhi perkembangan anak, antara lain; keluarga dan kematangan anak. Lingkungan keluarga merupakan aspek pertama dan utama dalam mempengaruhi perkembangan anak. anak akan lebih banyak menghabiskan waktunya di lingkungan keluarga, sehingga keluarga memeiliki peran dalam mebentuk kepribadia anak, memberikan contoh. Orang tua yang berperilaku baik maka anak akana cenderung meniru berperilaku baik ${ }^{13}$.. Hal ini sesuai dengan penelitian yang dilakukan Saputro dan Talan (2017) bahwa lingkungan keluarga memiliki pengaruh terhadap perkembangan psikososial anak.

Faktor-faktor yang mempengaruhi perkembangan psikososial anak usia 3-6 tahun adalah: ${ }^{14}$ 
a. Diri anak : 1). Pemahaman Diri, anak berpikir bahwa diri mereka dapat dijelaskan melalui banyak karakteristik material, seperti ukuran, bentuk, dan warna. Selain itu, anak-anak juga sering menggambarkan diri mereka dalam bentuk aktivitas permainan. 2). Harga Diri, harga diri adalah bagian dari evaluasi konsep diri, penilaian yang dibuat anak mengenai seberapa berhargannya mereka. 3). Pemahaman dan pengaturan emosi, kemampuan pengaturan emosi akan meningkatkan kemampuan sosial anak dan kemampuan bersosialisai dan mengungkapkan perasaan mereka

b. Gender : yaitu kesadaran yang berkembang pada masa anak-anak tentang jenis kelamin. Identitas gender melibatkan kesadaran gender seseorang, termasuk pengetahuan, pemahaman, dan penerimaan sebagai laki-laki atau perempuan. Pada umumnya anak .

c. Permainan: yaitu sebuah aktivitas yang menyenangkan dengan terlibat di dalamnya, ketika fungsi serta bentuknya bervariasi. Bermain adalah pekerjaan seorang anak, dan hal ini berkontribusi terhadap seluruh aspek perkembangan. Melalui bermain, anak merangsang indera, belajar menggunakan otototot mereka, mengkoordinasikan penglihatan dan gerakan, memperoleh penguasaan tubuh, dan memperoleh berbagai keterampilan baru.

d. Pengasuhan: setiap orang tua memiliki cara dalam mengasuh anak. terdapat empat jenis pengasuhan: 1). Pengasuhan otoriter (membatasi dan menghukum, harus mengikuti apa yang diinginkan oleh orang tua); 2). Pengasuhan otoritatif (mendorong anak-anak untuk menjadi mandiridan amsih dalam pengawasan orang tua); 3). Pengasuhan lalai (orang tua sangat tidak terlibat dalam kehidupan anak) ; 4). Pengasuhan permisif (orang tua terlibat dan memberikan tuntutan pada anak).

Pengetahuan orang tua tentang perkembangan anak dan stimulasi berperan penting dalam membantu anak mencapai tumbuh kembang. Terdapat hubungan antra penegetahuan $\mathrm{ibu}$ dengan perkembangan psikososial anak. $^{15}$

\section{Kesimpulan}

Hasil penelitian menunjukkan Terdapat pengaruh stimulasi motorik terhadap perkembangan psikososial anak usia pra sekolah di TK ABA Kecamatan Weleri. Anak yang mendapatkan stimulus sesuai usianya maka akan membanru anak mencapai perkembnagan sesuai usianya. Stimulasi motorik halus dengan menwarnai, menggambar, menggunting dapat membantu anak usia pra sekolah mencapai perkembnagan sosial. Perkembangan psikososial sebelum diberikan stimulasi motorik yang sesuai usia sebanyak 6 anak $(2,8 \%)$. Perkembangan psikososial setelah diberikan stimulasi motorik yang sesuai usia sebanyak 142 $\operatorname{anak}(67,3 \%)$.

\section{Saran}

Untuk mencapai tumbuh kembang sesuai tahapan usia, anak seyogyanya mendapat stimulus sesuai kebutuhan. Guru sekolah TK dan orang tua dapat memberikan stimulus untuk membantu tumbuh kembang anak.

\section{Daftar Pustaka}

1. Ujang. Konsep Dasar Perkembangan Potensi Motorik Anak Usia Prasekolah. Tahun VIII, No 12. (diakses tanggal 9 September 2018) 2011.

2. Soetjiningsih. Tumbuh Kembang Anak. Jakarta: EGC.2013.

3. Silawati.. Aspek Perkembangan Morik Dan Keterhubungannya Dengan Aspek Fisik Dan Intelektual Anak., from http://parentingislami.wordpress.com/2008/03/ 05/aspek-perkembangan-motorik-danketerhubungannya-dengan-aspek-fisik-danintelektual-anak,html.

4. Nuryani. (2009). Peranan Permainan Terhadap Aspek Gerak Motorik Pada Anak Taman Kanak-Kanak. Karya Tulis Guru Berprestasi Kabupaten Bantul.

5. Hurlock, Elizabeth B. Psikologi Perkembangan: suatu pendekatan sepanjang rentang kehidupan. Jakarta:Erlangga. 2011.

6. Adriana. Tumbuh Kembang dan Therapy Bermain pada Anak. Jakarta: Salemba Medika. 2011.

7. Hidayat, AA. Metode penelitian keperawatan dan teknis analisis data. Jakarta: Salemba Medika;2014.

8. Notoatmodjo, S. Metodologi penelitian kesehatan. Jakarta: Rhineka Cipta;2010.

9. Nursalam. Konsep dan penerapan metodologi penelitian ilmu keperawatan. Jakarta: Salemba Medika;2008.

10. Kartono,. Perkembangan psikologi anak. Jakarta: Erlangga;2008.

11. Wong, D.L, Hockenberry, M., Wilson, D., Winkelstein, M.L. \& Schwartz, P. Buku ajar keperawatan pediatrik Wong edisi: 6 (alih bahasa: Andri Hartono, Sari Kurnianingsih, Setiawan). Jakarta: EGC;2009. 
12. Sit, Masganti. Psikologi perkembangan anak usia dini .Depok: Penerbit Kencana;2017.

13. Saputro, H., dan Talan, Y.O. Pengaruh lingkungan keluarga terhadap perkembnagan psikososial anak usia pra sekolah. Jurnal of Nursing Practice. Vol:1 (1). Oktober 2017.

14. Santrock. Life-Span Development: Perkembangan Masa-Hidup. Edisi 13.Jilid 1. Alih Bahasa: Widyasinta Benedictine. Jakarta: Erlangga;2011.

15. Handayani, D.R., dan Puspitasari, N.P.D. (2009). Pengaruh terapi bermain terhadap tingkat kooperatif selama menjalanni perawatan pada anak usia pra sekolah (3-5 tahun) di RS Panti rapih Yogyakarta. Jaurnal Kesehatan Surya Medika Yogyakarta.
16. Rahmaulina, N.D. dan Hastuti, D. Hubungan pengetahuan ibu tentang gizi dan tumbuh kembang anak serta stimulasi psikososial dengan perkembangan kognitif anak usia 2-5 tahun. Jurnal Ilmu Keluarga \& Konsumen. Vol: 1 (2). (2008).

17. Harini N. (2013). Terapi warna untuk mengurangi kecemasan. Jurnal Ilmiah Psikologi Terapan. Vol. 1 (2) : 291-303.

18. Desni. (2010). Pelaksanaan Pembelajaran Bahasa Indonesia Bagi Anak Tuna Grahita Ringan Kelas III Di SLB Sabiluna Pariaman. Dalam Jurnal Ilmiah Pendidikan. Pariaman Sumatera Barat. 